\title{
The growth of signs
}

\author{
Winfried Nöth \\ Pontifícia Universidade Católica de São Paulo, \\ Programa de Estudos Pós-Graduados em Tecnologias \\ da Inteligência e Design Digital \\ Rua Caio Prado, 102 - CEP: 01303-000 - São Paulo, SP, Brazil \\ E-mail: noeth@uni-kassel.de
}

\begin{abstract}
The paper discusses the theory of semiosis in the context of Peirce's philosophy of evolution. Focussing on the thesis that symbols grow by incorporating indices and icons, it proposes answers to the following questions: What does Peirce mean by the "self-development of signs" in nature and culture and by symbols as living things? How do signs grow? Do all signs grow, or do only symbols grow? Does the growth of signs presuppose semiotic agency, and if so, who are the agents in semiosis when signs and sign systems grow? The paper discusses objections raised by culturalists and historical linguists against the assumption that signs can still grow and are still growing in complex cultures, and it draws parallels and points out differences between Peirce's theory of semiotic growth and the theories of memetics and teleosemiotics.
\end{abstract}

Keywords: C. S. Peirce, icon, index, symbol, memetics, teleosemiotics

\section{Growth, evolution, and the co-evolution of mind and the universe}

Biological organisms and species grow and evolve, but dead matter does not, as it seems; it can merely change. Nevertheless, growth is also attributed to lifeless things, such as floods, capital, costs, or economic output. We speak of urban "growth", growth in sales, economic growth rates, etc. - Peirce claims that "symbols grow" (CP 2.302 , c. 1895). It is certainly not unusual to hear that ideas, ideologies, dictionaries, or technical terminologies grow, but do they grow like organisms? In which sense can signs and sign systems be said to grow? Or is the use of the word "growth" with reference to ideas a "mere metaphor"? 
The premise of the title of this paper - that signs grow - is rooted in the evolutionary philosophy and semiotics of Charles S. Peirce. Evolution and evolutionism were the great themes of Peirce's time: "Today, the idea uppermost in most minds is Evolution," declared Peirce in 1901 (EP 2: 72), but his own contribution to the ongoing debate was not restricted to Charles Darwin's and Herbert Spencer's topics of biological and social evolution. It extended much further and included cosmogony (cf. Turley 1977) as well as the evolution of the laws of nature and of mind.

For Peirce, growth is a "law of mind" (CP 6.21, 1891), a law of the "general development of reason" (CP 1.615, 1903) as well as a law of the evolution of nature and the entire cosmos (CP 6.101g, 1901). Not only do phenomena, such as mind, thought, reason, and symbols grow. Even crystals are among the objects to which Peirce attributes growth, although he does not fail to specify that these grow in a different sense than living organisms do, namely by "merely attracting matter like their own" (CP 6.250, 1891). The difference between the growth of crystals and living organisms is that crystals grow according to a deterministic law, the "law of causation" (CP 8.330, 1904) in the sense of efficient causes, not of final causality (Santaella 1999). Evolutionary growth, by contrast, follows a different law. The law of evolution follows "the tendency to take habits" (CP 6.32, 1891). Whereas growth according to deterministic principles is a phenomenon of Secondness, the evolutionary tendency to take habits is a phenomenon of Thirdness: "Chance is First, Law is Second, the tendency to take habits is Third. Mind is First, Matter is Second, Evolution is Third," says Peirce in his "Architecture of Theories" (CP 6.32, 1891). ${ }^{1}$

1 However, this is not to say that physical nature belongs to the realm of Secondness in general, and only biological nature belongs to the realm of Thirdness. The evolution of nature is not only the evolution of biological nature. Physical nature has also its evolutionary history, and cosmic evolution is a matter of Thirdness, too. A more differentiated distinction between the kinds of action and reaction in the realm of physical laws and processes obeying the Law of Mind is the following: "Generally speaking genuine secondness consists in one thing acting upon another, - brute action. I say brute, because so far as the idea of any law or reason comes in, Thirdness comes in. When a stone falls to the ground, the law of gravitation does not act to make it fall. The law of gravitation is the judge upon the bench who may pronounce the law till doomsday, but unless the strong arm of the law, the brutal sheriff, gives effect to the law, it amounts to nothing. True, the judge can create a sheriff if need be; but he must have one. The stone's actually falling is purely the affair of the stone and the earth at the time. This is a case of reaction. So is existence, which is the mode of being of that which reacts with other things. But there is also action without reaction. Such is the action of the previous upon the subsequent. It is a difficult question whether the idea of this one-sided determination is a pure idea of secondness or whether it involves thirdness. At present, the former view seems to me correct. [...] The relation between the previous and the subsequent consists in the previous being determinate and fixed for the subsequent, and the subsequent being indeterminate for the previous. But indeterminacy belongs only to ideas; the existent is determinate in every respect; and this is just what the law of causation consists in" (CP 8.330, 1904). 
Growth is absent from the realm of genuine Firstness, the domain of phenomena such as chaos, chance, and spontaneity, but it is also absent from the domain of genuine Thirdness, the realm of phenomena such as absolute regularity, deterministic law, and petrified habit because when regularity and law prevail absolutely, change, as well as growth are no longer possible. Growth must therefore be sought in phases of transition and transformation, in the evolution from original Firstness to Thirdness as well as in those moments in which laws and habits become destabilized by disturbances, which give rise to new regularities and habits. This is Peirce's metaphysical account of cosmic growth (cf. Turley 1977). Cosmic evolution is growth from chaos to states of order repeatedly disturbed by spontaneous and unexpected new changes:

The evolution of the world [...] proceeds from one state of things in the infinite past, to a different state of things in the infinite future. The state of things in the infinite past is chaos, tohu bohu, the nothingness of which consists in the total absence of regularity. The state of things in the infinite future is death, the nothingness of which consists in the complete triumph of law and absence of all spontaneity. Between these, we have on our side a state of things in which there is some absolute spontaneity counter to all law, and some degree of conformity to law, which is constantly on the increase owing to the growth of habit. (CP 8.317, 1891)

The laws of nature did not exist as early as the beginning of the universe. They are the result of a growth of regularities out of an original chaos. This law of growth is guided by concrete reasonableness: "From the merest chaos with nothing rational in it, the universe grows by an inevitable tendency more and more rational" (MS 807: 16 , n.d.). Since growth is a characteristic of the expanding universe, this growth is itself growing so that it is self-reflexive. Habit taking is a habit itself, which accounts for the acceleration of habit taking in the course of evolution: "The tendency to form habits, or tendency to generalize, is something which grows by its own action, by the habit of taking habits itself growing" (CP 8.317, 1891).

The law of mind, which is "the primary and fundamental law of mental action", becomes apparent "in a tendency to generalization" (CP 6.21, 1891). This tendency is not "a figment of mind", as the medieval nominalists believed. It results from the more general laws of continuity (synechism) and from the premise that there is "reasonableness" in nature, an axiom of natural philosophy which Peirce attributes to Aristotle: "Every evolutionism must in its evolution eventually restore that rejected idea of law as a reasonableness energizing in the world [...] which belonged to the essentially evolutionary metaphysics of Aristotle" (EP 2: 72, 1901).

That the ever-growing "tendency to obey laws" (CP 1.409, 1890), which is characteristic of evolution, cannot be determined by blind laws, which admit no variation, is particularly evident in the evolution of mind. "Exact conformity [to the 
regularities of laws] would be in downright conflict with the law [of mind]; since it would instantly crystallize thought and prevent all further formation of habit", writes Peirce (CP 6.23, 1891). As long as the growth of mind goes on and we continue to have the freedom for "spontaneity counter to all law" (CP 8.317, 1891), evolution allows creativity and diversity.

The growth of symbols is particularly evident in the development of scientific knowledge, which is a special instance of the growth of symbols. Here, we encounter a self-reflexive loop similar to the one of growth, as discussed above. When human minds study the evolution of nature, they also study their own evolution. Nature has thus become self-reflexive: symbols, which have evolved from nature, begin to reflect on the nature from which they have evolved: "The laws of nature have, I suppose, been brought about in some way; and if so, it would seem that they were of such nature as inevitably to realize themselves" argues Peirce (EP 2: 72fn, 1901).

Nature, with its capacity to reflect on itself, has become self-similar in the sense that the scientific models or diagrams by means of which nature, at its present point of evolution, describes itself have structures inherent in nature before it became self-reflexive. The laws that human minds discover are the same laws as the ones from which human minds have evolved. In the discovery of nature through human minds, nature discovers itself. Peirce expresses these ideas in the following poetic image: "It is somehow more than a mere figure of speech to say that nature fecundates the mind of man with ideas which, when those ideas grow up, will resemble their father, Nature" (CP 5.591, 1903). In this sense, nature is not the object of study of science; it is one of the main agents in the process of research.

\section{The self-development of signs}

The growth of thought, ideas, or signs in general manifests itself in several forms and kinds. Peirce writes that "it is of the nature of thought to grow" (CP 2.32, c. 1902), and more emphatically, that "thought must live and grow in translation" (CP 5.594). Since "thought is always taking place by means of signs" (CP 1.444, 1896), growth of thought is at the same time growth of signs:

Thought $[\ldots]$ is in itself essentially of the nature of a sign. But a sign is not a sign unless it translates itself into another sign in which it is more fully developed. [...] Thought must live and grow in incessant new and higher translations, or it proves itself not to be genuine thought. (CP 5.594, 1903)

If signs grow incessantly and the growth of signs occurs in the process of the translation of a sign into another sign, which is the interpretant of a preceding sign, the 
process of semiotic growth is autopoietic in the literal sense of the word, that is, it is 'self-creative'. Signs grow self-creatively, but not in the sense of Maturana and Varela's radical theory of autopoiesis, which postulates that an organism grows "within a closed domain of relations specified only with respect to the autopoietic organization that these relations constitute" (Maturana, Varela 1980: 135). For Peirce, signs grow autopoietically in a different sense and not because of the allogpoietic agency of the sign users but because of the sign's inherent power to generate interpretant signs:

Semiosis - the generation of the interpretant - as always due primarily to the agency of the sign itself rather than to the agency of an interpreter, human or otherwise, does not deny that human agency has an important role in the occurrence of meaning phenomena, in changes in meaning, in the creation of meaning, and so forth. It does mean, though, that an interpreter's interpretation is to be regarded as being primarily a perception or observation of the meaning exhibited by the sign itself $[\ldots]$ and that such control as we do have over the powers of signs (thus over meaning phenomena in general) lies in our skill at setting them in interaction with one another in the compositional process in ways favorable to some desired result. (Ransdell 1992: 43)

The growth of symbols and thoughts does not only mean that signs grow autonomously in the above-specified sense and that they acquire new meanings. It also means that there is a development from signs of a more primitive kind to "more fully developed" signs, as Peirce put it in the above quote of 1903. In the process of their growth, symbols do not only grow in meaning, but they also, self-referentially, give evidence of their own growth. The degree to which they do so testifies to the degree of their evolution: "The highest kind of symbol is one which signifies a growth, or self-development, of thought [...], and accordingly, the central problem of logic is to say whether one given thought is truly [...] a development of a given other or not" (CP 4.9, 1905). The key term here, which captures Peirce's theory of autopoiesis concisely, is 'self-development'. Symbols and the reasons contained in the logic of their arguments grow alone because, in the long run, arguments which lack reasonableness have an inherent tendency to being superseded by more reasonable ones. Although they need their defenders in order to be divulged, strong arguments and good reasons spread with an agency that is in a way independent from the agency of those who disseminate them:

Whatever one's theory may be as to the invalidity of human reason, there are certain cases where the force of conviction practically cannot be resisted; and one of these is the experience that one opinion is so far from being as strong as another in the long run, though it receives equally warm support, that on the contrary, ideas 
utterly despised and frowned upon have an inherent power of working their way to the governance of the world, at last. True, they cannot do this without machinery, without supporters, without facts; but the ideas somehow manage to grow their machinery, and their supporters, and their facts, and to render the machinery, the supporters, and the facts strong. [...] Most of us, such is the depravity of the human heart, look askance at the notion that ideas have any power; although that some power they have we cannot but admit. The present work, on the other hand, will maintain the extreme position that every general idea has more or less power of working itself out into fact; some more so, some less so. (CP 2.149, 1902)

\section{How symbols grow by incorporating icons and indices}

The evolution from Firstness to Secondness and Thirdness, which began with the origins of the universe, has a parallel in the way signs develop from icons, which are signs of Firstness, via indices (signs of Secondness), to symbols (signs of Thirdness). Icons are needed to show what we are talking about and indices to connect our thoughts to the reality which they represent. Symbols are associated to the objects they represent by habits (cf. Nöth 2010), but habits cannot change as such, nor can they arise out of nothing. They can only become stronger or weaker. A new habit, by contrast, must begin with new experiences, which involves indexical and iconic signs. This is why symbols cannot grow by themselves. "A symbol, in itself," says Peirce, "is a mere dream; it does not show what it is talking about" (CP 4.52, 1893).

Likewise, indices cannot grow alone. A sign that has grown conveys more information than it did before. An index alone cannot grow because it has a strictly local signification and is devoid of the generality necessary for a sign to be informative: “The index asserts nothing; it only says 'There!' It takes hold of our eyes, as it was, and forcibly directs them to a particular object, and there it stops" (CP 3.361, 1885).

A pure icon cannot grow either. It signifies because of qualities inherent in itself (see Nöth 2003b). Qualities, however, are what they are, but they cannot grow. Furthermore, pure icons are always vague and without real referents since they only represent qualities. This is why "the idea embodied by an icon [...] cannot of itself convey any information, being applicable to everything or to nothing" (CP 3.433, 1896), although icons, especially in the form of diagrams and mental images, are able to modify symbols and can thus contribute to their growth (see Nöth 2012b, 2014b).

Concerning the contribution of icons to the growth of symbols, Peirce writes: "Symbols grow. They come into being by development out of other signs, particularly from icons, or from mixed signs partaking of the nature of icons and symbols" (CP 2.302, 1893). The necessary participation of indices in the growth of symbols is addressed when Peirce specifies that symbols grow the more towards 
perfection, the more they incorporate icons and indices and that "the most perfect of signs are those in which the iconic, indicative, and symbolic characters are blended as equally as possible" (CP 4.448, 1903). The notion of the "most perfect of signs" implies that there are degrees to which symbols have incorporated iconic and indexical elements in the course of their growth.

How symbols grow by incorporating icons and indices is the topic of Peirce's theory of information (Nöth 2012a). Typically, they grow in the form of symbolic dicents. Dicents are signs which have the form of a proposition and which can be true or false. An example of an informative and true verbal dicent is: Whales are mammals.

According to Peirce's reinterpretation of the medieval distinction between signification and denotation, a proposition incorporates an index in its subject term and an icon in its predicate term. The index is the part of a dicent that denotes. It does so by selecting a specific object, here whales, about which the predicate might give further information. The predicate is the iconic part of the symbolic dicent. It signifies by evoking images of qualities or characteristics of the object. In sum: "A proposition consists of two parts, the predicate which excites something like an image or dream in the mind of the interpreter, and the subject, or subjects, each of which serves to identify something which the predicate represents" (MS 280: 32, c.1905).

Against this background, informational growth can take place both in the subject or index part of the proposition and, independently of it, in its predicate or icon part (CP 2.419, 1893). The sentence Whales and cows are mammals exemplifies an indexical growth in relation to the above proposition since the class of denotata selected by the proposition has increased in comparison to the proposition Whales are mammals. The sentence Whales are aquatic mammals exemplifies an iconic increase since the qualities attributed to the subject have become more.

Symbols do not only grow in the form of dicents and arguments but also as concepts or terms, which are rhematic signs. Concepts grow with the increase of knowledge or amount of information that they have accumulated in the course of time. Icons and indices participate insofar in the growth of rhematic symbols as the denotation of a concept implies an index and its signification implies an icon. Peirce illustrate the concept growth as follows: "Such words as force, law, wealth, marriage, bear for us very different meanings from those they bore to our barbarous ancestors" (CP 3.608, 1903). The growth of meaning exemplified by these words is not reflected in an increase of verbal or lexical meaning but in encyclopaedic knowledge. This knowledge grows in parallel with the growth of science: "The woof and warp of all thought and all research is symbols, and the life of thought and science is the life inherent in symbols" (CP 2.220, 1903). 
The history of the word electricity may serve as an example (CP 5.313, 1893; MS 905, 1907; cf. Short 1988: 86). The Oxford English Dictionary, in its edition of 2001, summarizes it as follows:

Electricity, n. [...]: In early use: the property of amber, glass, and certain other substances of attracting lightweight objects when rubbed [...]; (also) the state produced in such substances by rubbing. Subsequently: the cause of this phenomenon (and of others found to be of the same origin, such as electric sparks and lightning), a form of energy occurring in two modes (positive and negative) as an intrinsic property of electrons and certain other subatomic particles, and produced as a flowing current when a conductor such as a copper wire is moved through a magnetic field.

Benjamin Franklin considered electric phenomena to be due to a fluid [...]. Later in the 19th cent. the prevailing view was that electricity is a distinctive condition either of the molecules of an electrified object or of the ether surrounding it.

The example shows how one and the same word has grown both through the addition and subtraction of characteristics attributed to it and how the word, since its first coinage in the early 17 th century, has made progress in its fitness to represent the object of the sign, that is, electricity. In the growth of the term, Peirce sees elements of life and concludes: "Every symbol is a living thing, in a very strict sense that is no mere figure of speech. The body of the symbol changes slowly, but its meaning inevitably grows, incorporates new elements and throws off old ones" (CP 2.222, 1903).

Knowledge grows through interpretation, or as Peirce puts it: in their interpretants, signs grow in information (CP 3.608, 1908). Knowledge is produced in a process in which a sign is interpreted in the form of a new and more informative sign, the latter being the interpretant of the former. Not all interpretants of symbols are informative. Feelings and spontaneous reactions, for example, are uninformative. Informative interpretants are the signs through which symbols grow. In metaphors borrowed from characteristics of living organisms, Peirce describes how terms grow in their interpretations as follows:

The process of getting an equivalent for a term is an identification of two terms previously diverse. It is, in fact, the process of nutrition of terms by which they get all their life and vigor and by which they put forth an energy almost creative - since it has the effect of reducing the chaos of ignorance to the cosmos of science. Each of these equivalents is the explication of what there is wrapt up in the primary - they are the surrogates, the interpreters of the original term. They are new bodies, animated by that same soul. I call them the interpretants of the term. And the quality of these interpretants, I term the information or implication of the term. (W 1: 464-65, 1866) 
In language, symbol growth has two forms. Either an existing word acquires new meanings, as the word electricity did in the course of its history, or a neologism is coined, which increases the existing vocabulary. Peirce describes the creation of neologisms as an autopoietic process in the above-defined sense, when he states that new symbols can only be created by means of symbols, for example, in the form of a definition of a new word: "If a man makes a new symbol, it is by thoughts involving concepts. So it is only out of symbols that a new symbol can grow. Omne symbolum de symbolo" (CP 2.302, 1893).

Peirce illustrates how symbols are able to create new symbols by the hypothetical example of a new trade name introduced for a gas stove entering the market: "Perhaps the most marvelous faculty of humanity is one which it possesses in common with all animals and in one sense with all plants, I mean that of procreation. [...] If I write 'Let Kax denote a gas furnace', this sentence is a symbol which is creating another within itself" (W 1: $497=$ CP 7.590, 1866).

The self-creativity of symbols is rather multifaceted. That symbols stem from symbols does certainly not mean that they only descend from symbols. Above, we concluded already that new symbols have also icons and indices at their root. Another semiotic premise of the omne symbolum de symbolo dictum is that signs in general are the premise as well as the consequence of signs. They do not originate from nonsigns, from some presemiotic state of unmediated (or immediate) perception. Peirce had defended this theory since his 1868 paper on "Questions concerning certain faculties claimed for man", in which he had developed the doctrine that whenever there is a sign, there must have been a sign that preceded it (cf. Linde, Nöth 2014).

\section{Culturalist objections against the idea that symbols grow}

Objections against the theory that signs have characteristics of living organisms are not hard to find (e.g., Kull 2002), but signs in Peirce's definition are not only words; they are ideas in a much broader sense, which includes texts, books, ideologies, paradigms, whole languages, and cultures.

There are two historical objections against the assumption that symbols in this broader sense should evince growth. The first is that symbols are in constant decline. We find it in antiquity as the myth of the evolution of a Golden via a Silver and a Bronze Age towards an Iron Age of humanity. In the early 20th century, it was Oswald Spengler who propagated an influential decline theory in his treatise on the Decline of the West. In a semiotic guise, the idea of decline reappeared decades later, when Baudrillard declared that we have reached a crisis of representation in which the signs have lost their referents and only empty catch phrases have survived (cf. Nöth 2003a). 
However, the cultural pessimists who reject the idea of growth are not concerned with the growth of knowledge, science, and theoretical concepts. They deplore the decline of social and cultural life styles, fashions, of the "grand narratives" (Lyotard), of life on the screen, wars that have become mere fiction or monetary systems in whose values they see only loss and no gain. When Baudrillard and others deplore the loss of the referents in the signs in the media of contemporary culture, they are not talking about the progress or lack of progress reflected in the symbols of scientific research. They want to comment on how representations of cultural and social life have changed. Notice that Baudrillard does not extend his thesis of the loss of the referents to his own discourse. When he thus protects his own socio-semiotic analyses from the scope of what he criticizes, he makes a distinction between intellectual or theoretic discourse, arguing that the latter deserves exemption from his thesis of the loss of the referent and the discourse found in popular culture, which is the goal of his critique.

A fundamental difference between the views of those who do not believe that symbols grow and Peirce's views to the contrary is in the assumption concerning the degree zero from which the growth or decline of symbols should be measured. Those who postulate the decline of the referent in films in the age of digital imaging (see Lefebvre, Furstenau 2002) or even the decline of cultures in our contemporary society presuppose, whether explicitly or implicitly, that the symbols we are using today formerly represented values which they no longer represent. However, the arguments remain vague or even nostalgic as long as the critics do not specify the values that are supposed to have gone lost.

In his theory of semiosis, Peirce is neither concerned with social or moral values nor with the alleged decline of cultural values. Instead, his topic is the growth of knowledge. Knowledge does not only grow because of the incessant endeavour of researchers to discover new facts and laws of mind and nature. The symbols that represent the laws of nature also have an inbuilt mechanism that makes them grow because of a property of their own. As paradoxical as it may sound, this property is their incompleteness. The very incompleteness of the symbols representing their field of research urges researchers to advance their studies. Due to their generality and fuzziness, symbols are by necessity imperfect. By the researcher's efforts to overcome this incompleteness, symbols continue to grow. Imperfection is the opposite of generality, so that the law of increasing generality predicts the eradication of imperfections:

So, then, the essence of Reason is such that its being never can have been completely perfected. It always must be in a state of incipiency, of growth. [...] The development of Reason consists, you will observe, in embodiment, that is, in manifestation. The creation of the universe [...] is this very development of Reason. (CP 1.615, 1903) 
The second argument against the idea of the growth of symbols is that languages and cultures have essentially no longer grown since the earliest languages about which we have knowledge. In modern linguistics, the consensus is that no known language is more developed than any other is. There are only differences, but no language is more advanced than another. Languages can neither progress nor decay. All languages are equally complex and equally evolved, albeit in different ways (Aitchison 2013). The counterpart in cultural theory is that all cultures are equally complex and equally fit to survive. This is essentially the position of the culturalists and cultural relativists.

However, the evidence given by those who claim that there is no more progress in language is almost exclusively a phonological, morphological, or syntactic one. However, such evidence cannot invalidate Peirce's theory of the growth of symbols, which is concerned with the growth of knowledge in general and of scientific concepts in particular. Peirce is not concerned with the grammar of symbols but with knowledge representation. Although his theory does not predict why certain phonological or grammatical structures become extinct, whereas others survive, nor why some grammatical structures are "optimal" whereas others are not, it can explain why and in which direction vocabularies and terminologies grow. That there is growth in language in this sense has been postulated a century and a half ago by Charles Lyell with arguments that can still today hardly be refuted. Darwin's contemporary wrote: "Progressive improvement in language is a necessary consequence of the progress of the human mind from one generation to another. As civilisation advances, a greater number of terms are required to express [...] ideas and things, which a single word had before signified, though somewhat loosely and imperfectly" (Lyell 1863: 467).

\section{Historical and evolutionary linguists on the growth of symbols}

The growth of symbols should be high on the research agenda of biosemiotics, biolinguistics, cultural anthropology, the theory of cultural evolution, evolutionary cultural semiotics, evolutionary linguistics, and the theory of evolution in general. Is it really? The diffusion of human symbolism out of Africa across the rest of the globe is undeniably a scenario of the growth of symbols, but mere diffusion is only quantitative growth. Theories of the growth of meaning and knowledge are scarce although such growth is undeniable. It must suffice to illustrate this state of art in two domains of research, historical and evolutionary linguistics.

Historical linguistics has studied laws of language change, not of growth, as described above. None of the classical laws of sound, morphological, syntactic, or semantic change formulated since the early 19 th century is a law of growth. Semantic 
change, for example, has been described in terms of broadening, narrowing, shift, or metaphorical and metonymic change. Broadening and metaphorical extensions are candidates for a theory of growth, but such growth is usually accompanied by processes of narrowing. For example, the English word $d o g$ has broadened its meaning some seven hundred years ago from the meaning of a particular kind of dog to 'dog in general', but there was no growth since the new meaning of $d o g$ is essentially the same as the meaning which was previously expressed by the older word hund. The older word simultaneously narrowed its meaning to its present meaning.

The lack of attention given to the topic of growth may be less obvious in evolutionary linguistics since in the study of the origins and the evolution of language, the growth of symbols is too obvious. However, if we look at biolinguistics, the Chomsky-inspired variant of evolutionary linguistics, we can see that not symbols and their growth are being studied but the anatomical and genetic evolution of symbol users, that is, the evolution of the species of Homo sapiens sapiens.

In contemporary biolinguistics, there is the tendency to naturalize symbols in the search for their origins. The hot topic is the question of how language is localized in the anatomy of the cerebrum and in human genes. The hope is to unveil the mystery of the origins of language with methods of the natural sciences. Instead of asking how signs grow, biolinguists ask how the human language capacity can be accounted for by anatomical or genetic evidence. Semiotic growth becomes a matter of biological growth. That this approach may lead in the wrong direction, as far as the origins of semiosis is concerned, was suggested by Peirce more than a century ago. In his famous inkstand parable, Peirce suggested that the brain lobe which enables a writer to write is as much the writer's tool as the technical medium of writing, the paper, the pen and the ink; today we can add the personal computer, which are as necessary to write down his or her ideas as the brain is (cf. Nöth 2002).

Undoubtedly, linguists and anthropologists have made much progress in solving the riddle of the origins of language. The state of the art of the research results can hardly be reviewed here; a brief look at the question of the growth of symbols must suffice. Have symbols grown from indices and icons as Peirce's evolutionary semiotics suggests? What is the evolutionary evidence? What are the relevant hypotheses?

That indexical signs must be the immediate evolutionary precursors of symbols, and icons the precursors of indices, has been argued most convincingly by Deacon (1997: 70-75, 87) with evidence from the primate research programme of the 1980s. Apparently, the verbal symbols of humans are first and essentially only learned as indices by chimpanzees, and the sequence icon-index-symbol is also characteristic of language acquisition in humans. Complementary research comes from Merlin Donald (1991: 226), whose book on the Origins of the Modern Mind postulates an early iconic phase in the evolution of human symbols in which "mimetic representation" based on "mental modelling" took place. 
Nevertheless, the role of the icon in the evolutionary growth of symbols seems to be less well understood than the one of the index, at least from the perspective of Peirce's broader theory of iconicity. Deacon speaks of "iconic reference" and interprets icons as signs recognized as such because of their similarity with their objects. Donald speaks of "the principle of similarity that links mimetic actions and their referents" (1998: 61). However, the term "iconic reference" is a contradiction in terms if icons are defined as Peirce defines them. For Peirce, icons have no referents at all. As images, they represent qualities, and as diagrams, they represent general patterns. Such characteristics of icons in particular can shed light on the transition from symbols that are mere words and symbols that have evolved syntactic structures.

\section{The agency and life of symbols}

Another aspect of the Peircean theory of semiotic evolution that needs to be considered briefly is the one of the autonomous agency of the symbol in relation to its users (cf. Nöth 2002, 2009). A brief look at some of the above quotes reveals what it is about. Instead of symbol makers who create new signs, Peirce speaks of the "selfdevelopment" of symbols. Not only does he attribute "life and vigor" to symbols and "strength" to arguments, but - horribile dictu - he even speaks of symbols which have grown to "new bodies animated by the same soul" (see above; W 1: 464-65, 1866).

Peirce knew well that scholars committed to the humanist tradition could only look askance at such ideas. Signs are instruments of human minds, and human sign makers use them with intentions of their own. This is their credo (see Nöth 2009). For Peirce, by contrast, human sign makers are not fully autonomous agents, who use signs as mere instruments to extend their minds, for the semiotic agency of sign users is also controlled by the meanings inherent in the symbols they use, the power of ideas, and the logic of valid arguments. The sign is not "given" a meaning by its users; it does not "receive" its meaning from its interpreter. Before it becomes actually interpreted, the symbol has already a meaning in the sense of an interpretative potential. Peirce defines this meaning as the immediate interpretant of the sign, and says that it "is implied in the fact that each Sign must have its peculiar Interpretability before it gets any Interpreter" (SS 110-11, 1909). The same holds true for ideas in general, which are, or course signs, too. Good and true ideas do not only have a potential but also an inherent power to succeed. "Ideas are not all mere creations of this or that mind, but on the contrary have a power of finding or creating their vehicles, and having found them, of conferring upon them the ability to transform the face of the earth" (CP 1.217, 1902).

Peirce's above quoted insight that "it is only out of symbols that a new symbol can grow" (CP 2.302, 1893) is also true of ideas, by which Peirce means symbols insofar 
as they enable us to have thoughts, irrespective of whether we actually think them (cf. CP $6.455,1908)$. Like symbols, ideas grow through an agency of their own, and in this process, the "souls" of those who use these ideas, have no full power over them either. Nor do ideas grow as a mere reflex of the facts that they represent. That ideas need the agency of sign users to spread is undeniable. However, it is only the very ideas that enable sign users to have thoughts and to communicate at thoughts at all:

Many logicians [say] that ideas arise from the consideration of facts in which there are no such ideas, nor any ideas. That opinion is a superficial one [...]. So, those logicians imagine that an idea has to be connected with a brain, or has to inhere in a "soul". This is preposterous: the idea does not belong to the soul; it is the soul that belongs to the idea. The soul does for the idea just what the cellulose does for the beauty of the rose; that is to say, it affords it opportunity. It is the court-sheriff, the arm of the law. (CP 1.216, 1902).

\section{Memes and the teleosemiotic theory of semiotic growth}

Dawkins's (1976) theory of memes and some of the subsequent theories based on Dawkins's premises seem to offer independent support to Peirce's theory of the life of signs in semiosis. Like Peirce, Dawkins attributes life to signs. In Dawkins's definition, memes are semantic or informational elements endowed with the capacity of copying or 'replicating' themselves. In this way, they become disseminated in the minds of the members of a culture. Some of the authors who have extended Dawkins's premises refer to memes as viruses, which spread by contagion (see also Nöth 2012c). A Darwinist component of the theory of memetics is the assumption that genes disseminate according to the laws of natural selection.

It is neither necessary nor possible to elaborate on the details of memetics, which are well-known. From the perspective of biosemiotics, Deacon (1999) and Kull (2000) have addressed some of its weak points. The authors point out that the processes of copying, self-reproduction, and replication of genes differ from the ones of the dissemination of signs. What is of interest here is not another critique of memetics, but the question whether the replication of memes, as conceived by Dawkins and other theoreticians of memetics, can exemplify the growth of symbols as defined by Peirce. The answer is essentially no. From Peircean premises, the mere replication of memes would have its semiotic analogue in the replication of a symbol through its types, that is, the instances of its use in specific situations. The replication of a symbol type in the form of its tokens is certainly a prerequisite, but not a sufficient condition for the growth of a symbol. A necessary condition of symbol growth is an interpretant, in which the meaning of the symbol can grow, but a symbol token is not the interpretant of the symbol. A symbol is a type, of which its tokens are its mere instantiations. 
The same objection applies to a line of research in cognitive semiotics discussed elsewhere under the name of teleosemiotics (cf. Nöth 2009). It includes Millikan's teleosemantics, Dretske's teleofunctionalism, and Papineau's teleological theory of representation (Dretske 1983, 1988; Papineau 1987). Millikan's teleosemantics, for example, in contrast to what her key term suggests, is not only concerned with language since she, a former student of Charles Morris, extends her philosophical interpretation of the role of language in culture to the one of material objects, such as tools and technological devices.

In contrast to the mainstream doctrines of intentionality in verbal behaviour, as defended by Chomsky, Fodor, Searle, or Grice, which define speakers' intentions as the sole cause of language utterances, Millikan, like Peirce, ascribes autonomous purposes to the signs by which speakers communicate. The purpose of a sign, according to Millikan, is its "proper purpose" or "proper function". Millikan's teleosemiotics is rooted in the Darwinist theory of biological evolution (Millikan 2004: 14-27), and the author does not fail to acknowledge her indebtedness to Dawkins's theory of memes (Dawkins 1976) with its postulate that cultural products, such as words, catch phrases, slogans, or melodies, spread in human minds like genes spread in living species.

Millikan argues that ultimately all signs, even intentional verbal signs, have evolved from natural signs such as the ones of nonverbal animal behaviour. The difference which she sees between the signs of animals and those of human language is that the former are genetically replicated, whereas the latter are replicated by learning, that is, in the form of sign tokens (re)produced from "some earlier token or tokens of its type that the speaker has heard" (Millikan 1984: 22). In the long process of their divulgation through replication, cultural signs "never lose their character of being also natural signs" (Millikan 2004: 105). Like the nonverbal signs of animals, words and sentence patterns survive as sign types by being reproduced in the form of their tokens (Millikan 2005: 3). All cultural signs have their own "reasons for survival" (Millikan 1984: 28). A major purpose of natural and cultural signs is to be replicated in their usage. Millikan describes the reasons for the survival of signs as follows:

Artifacts that have been serving certain functions known to those who reproduce them and that are reproduced on this account (e.g., household screwdrivers) have these functions as direct proper functions. Behaviors that result from training or from trial and error learning involving correlations of a reward with the behavior have as direct proper functions to produce that reward. Behaviors that result from imitation of behaviors of others because the latter behaviors have correlated, within the observation of the learner, with certain functions have these functions as direct proper functions. (Millikan 1984: 28) 
The final causes of the replication of words and of the patterns of verbal syntax are the effects which utterances have in successfully coordinated acts of verbal communication (Millikan 2005: 45): “Conventional language devices are selected for performing services satisfactorily at once to both partners in communication" (Millikan 2004: 26) since "a primary function of the human language faculty is to support communication" (Millikan 2005: 39). The form of a speech act that succeeds in implanting the speaker's belief in the hearer's mind is "selected for reproduction" and is replicated (ibid.: 39). The grammatical form of the indicative mood, for example, survives because of the success which sentences in the indicative mood have in contrast to sentences in the subjunctive or imperative mood. Sentences in the indicative mood are verbal forms serving successfully as "guides in forming beliefs"; without the success in the use of this grammatical form, "speakers would stop trying to use them to impart beliefs. Production of true beliefs, then, is a linguistic function, a purpose, of the indicative form itself, whether or not a particular speaker and/or hearer have as their own purpose to use it in that way on a given occasion" (Millikan 2005: 190-91).

The "proper purpose" which a sign has independently of its user is hence to survive and to proliferate by staying in circulation (Millikan 2005: 53). Not restricted to a theory of verbal signs, Millikan's teleosemiotics is a general theory of signs (Millikan 1984: 85), which explains the replication of genetically transmitted sign behaviour of animals as well as the proliferation of artefacts in culture. The purpose of a "technological meme", such as an arrow whose design is copied again and again because it shoots well, is self-replication "by serving people's prior interests" (Millikan 2004: 18). Millikan gives the following evolutionary account of the main difference between signs and instruments: artefacts, such as tools and other instruments, have individual inventors, and their inventions, if successful, tend to be replicated. Verbal signs, by contrast, evolve like species or body organs, which have no individual inventor but stem from an ancestor whose genes have proliferated (Millikan 1984: 3). Furthermore, there is a difference in how they replicate. Whereas words are replicated from one or many tokens in the process of language learning, instruments are signs that are always replicated from a type: "Items produced by mass production are usually reproductions of some prototype not produced on the line - some original experimental model" (Millikan 1984: 21). Words are not replicated by means of genes, but from precedents and conventions "thought to have little tendency to emerge or re-emerge in the absence of precedent" (Millikan 2005: 7). Language conventions are "lineages of behavioural patterns" repeating precedents of successful communicative interactions (Millikan 2005: 86).

A thorough analysis of the affinities and differences between Peirce's general semiotics and Millikan's teleosemiotics is a desideratum of current semiotic research, 
but in our context, which is restricted to the growth of signs, the following conclusion can suffice:

(1) Millikan's concept of sign is much narrower that Peirce's theory of the sign. Her restriction to signs of human beings and signs in animal behaviour reduces her semiotics to the field of anthroposemiotics and zoosemiotics, ignoring the broader implications of biosemiotics, the semiotics of nature and certainly the semiotics of machines.

(2) Millikan's account of signs surviving as types reproduced in the form of tokens shows the restriction of her semiotics to symbolic legisigns and their replicas; her semiotics ignores the role of qualisigns, sinsigns, iconic, and indexical signs in the growth of signs.

(3) Millikan's theory of semiotic teleology and her views concerning the purpose of signs are much narrower than Peirce's teleological theory of semiosis (see, e.g., Short 1983).

(4) Whereas Millikan's teleosemiotics is restricted to the Darwinist biological paradigm of evolution, in which self-replication and survival of the fittest is the evolutionary purpose of genes, species and, by extension, signs, Peirce's general semiotics is also a logic of signs. Signs are not only self-replications in the infinite process of semiosis, they also develop in a process of semiotic growth: "The purpose of signs" says Peirce (CP 2.444, fn, c.1893), “- which is the purpose of thought - is to bring truth to expression".

\section{Conclusion and further perspectives}

The growth of signs, as Peirce sees it, is the growth of knowledge. Only symbols can grow and represent more knowledge than they did before, but symbols cannot convey any knowledge without indices, which connect them with facts and experience, and without icons, which create mental images of the objects they represent. The growth of symbols through the incorporation of icons and indices is autopoietic in the sense of 'self-creative'. Although symbols need sign makers and users as agents to convey their message, these agents are not fully autonomous in the making of new symbols and in attributing new meanings to them. Symbols are not organisms of flesh and blood, but they do replicate themselves like organisms do, and, in their process of their replication in new contexts, symbols grow in meaning.

The growth of symbols is a topic of such multi-faceted and far-reaching implications in the framework of Peirce's theory of semiosis that only some of its implications, presuppositions, and consequences could be addressed within the limited scope of this paper. For those interested in the study of further aspects of this topic, 
some brief references to further implications of this topic might be useful before concluding this paper.

The first is vagueness and incompleteness as prerequisites for the growth of symbols. Symbols can only grow because they represent their objects incompletely. In the course of their growth, they tend to represent their objects more and more completely, but no symbol (the term includes books and whole libraries) will ever represent its object without some remaining incompleteness. A world of symbols that would represent its objects completely would be a world in which semiosis had ended. Nothing would remain to be inquired (cf. Nöth, Santaella 2011).

A second aspect to be pursued in further studies is the growth of symbols from mere words to habits (of thought and action) and habit change (Nöth 2010). In MS 283 (103-104, 1905), as summarized by Kent (1987: 197), Peirce made it clear that "an endless series of signs, which never get realized in action but are translated into nothing but signs, would not show any growth". This aspect of their growth is implied in Peirce's pragmatic maxim and it is a consequence of Peirce's postulate that semiosis that ends in mere words is incomplete. Words merely express verbal meanings, which are "very inferior to the living definition which grows up in the habit" (CP 5.491, 1907).

Further aspects of the topic are the role of creativity and abductive reasoning (Anderson 1987), the growth signs in learning (Nöth 2014c, d), and the biosemiotic implications of the growth of signs (Nöth 2014a). Do symbols really "grow" as biological beings do, or is it a "mere metaphor" to speak of the growth of symbols?

Let us conclude with still another, certainly not the last, aspect of this topic, the one of the critical voices against Peirce's theory of the autonomy of signs. As briefly mentioned above, Peirce, with his idea that symbols grow autonomously, risked a scandalon among anthropocentric and humanistic minds, many of whom have decided to ignore Peirce's ideas in this regard. One who has made his opposition explicit is John Boler (1964). The author objects to Peirce's thesis of the relative autonomy of the symbol in relation to its producers and interpreters. As Boler sees it, "Peirce does not avail himself of the standard kind of argument: that [...] a deed that must have a doer". The alleged "error" in the theory of the autonomous growth of symbols is that Peirce "dispensed with the individual mind that functions as an interpreter" (Boler 1964: 388) and that "in denying the interpreter any significant role, Peirce has placed an intolerable burden upon the series of interpretants" (Boler 1964: 392). Half a century after this critique, in the light of new insights into evolution as co-evolution, into the situatedness of human cognition, and into the place of humans in an umwelt that restricts their semiotic autonomy, a thorough revision of Boler's anthropocentric critique of Peirce's insights into the growth of symbols is high on the agenda of contemporary research. 


\section{References}

Aitchison, Jean 2013. Language Change: Progress or Decay. [4th ed.] Cambridge: Cambridge University Press.

Anderson, Douglas R. 1987. Creativity and the Philosophy of C. S. Peirce. Dordrecht: Nijhoff.

Boler, John F. 1964. Habits of thought. In: Studies in the Philosophy of Charles Sanders Peirce II. [Moore, Edward C.; Robin, Richard S. (eds.).] Amherst: Massachusetts University Press, 382-401.

CP = Peirce, Charles S. 1931-1958. Collected Papers of Charles Sanders Peirce. Cambridge: Harvard University Press. [Hartshorne, Charles; Weiss, Paul (eds.), 1931-1935; vols. 7-8. Burks, A. W. (ed.) 1958; In-text references are to CP, followed by volume and paragraph numbers.]

Dawkins, Richard 1976. The Selfish Gene. [Rev. ed. 1989] Oxford: Oxford University Press.

Deacon, Terrence W. 1997. The Symbolic Species: The Co-Evolution of the Brain and Language. New York: Norton.

- 1999. Memes as signs. The Semiotic Review of Books 10(3): 1-3.

Donald, Merlin 1991. The Origin of the Modern Mind. Cambridge: Harvard University Press.

- 1998. Mimesis and the executive suite. In: Hurford, James R.; Studdert-Kennedy, Michael; Knight, Chris (eds.), Approaches to the Evolution of Language. Cambridge: Harvard University Press, 44-67.

Dretske, Fred 1983. The Nature of Psychological Explanation. Cambridge: MIT Press.

- 1988. Explaining Behavior. Cambridge: MIT Press.

EP 2 = Peirce, Charles S. 1998. The Essential Peirce. Selected Philosophical Writings. Volume 2 (1893-1913). [The Peirce Edition Project (ed.)]. Bloomington: Indiana University Press.

Kent, Beverly 1987. Logic and the Classification of the Sciences. Kingston: McGill-Queen's University Press.

Kull, Kalevi 2000. Copy vs. translate, meme vs. sign: Development of biological textuality. $S$. European Journal for Semiotic Studies 12(1): 101-120.

- 2002. A sign is not alive - a text is. Sign Systems Studies 30(1): 327-335.

Lefebvre, Martin; Furstenau, Marc. 2002. Digital editing and montage: The vanishing celluloid and beyond. Cinémas: Revue d'études cinématographiques 13(1-2): 69-107.

Linde, Gesche; Nöth, Winfried. 2014. A note on Peirce's quotations of Persius's half-line hoc loquor inde est. Transactions of the Charles S. Peirce Society 50.2.

Lyell, Charles 1863. The Geological Evidences of the Antiquity of Man, with Remarks on Theories of the Species by Variation. [2nd rev. ed.] London: Murray.

Maturana, Humberto R.; Varela, Francisco J. 1980. Autopoiesis and Cognition. Dordrecht: Reidel.

Millikan, Ruth 1984. Language, Thought, and Other Biological Categories: New Foundations for Realism. Cambridge: MIT Press.

- 2004. Varieties of Meaning. Cambridge: MIT Press.

- 2005. Language: A Biological Model. Oxford: Clarendon.

MS = Peirce, Charles S. ([1963-1966]1979). The Charles S. Peirce Papers. [30 reels, 3rd microfilm edition.] Cambridge: The Houghton Library, Harvard University, Microreproduction Service. [In-text references are to MS, followed by manuscript number according to Robin.]

Nöth, Winfried 2002. Semiotic machines. Cybernetics \& Human Knowing 9(1): 5-22.

- 2003a. Crisis of representation? Semiotica 143(1-4), 9-16.

- 2003b. Semiotic foundations of the study of pictures. Sign Systems Studies 31(2), 377-392. 
- 2009. On the instrumentality and semiotic agency of signs, tools, and intelligent machines. Cybernetics \& Human Knowing 16(3-4): 11-36.

- 2010. The criterion of habit in Peirce's definitions of the symbol. Transactions of the Charles S. Peirce Society 46(1): 82-93.

- 2012a. Charles S. Peirce's theory of information: A theory of the growth of symbols and of knowledge. Cybernetics \& Human Knowing 19(1-2): 99-123.

- 2012b. Medieval maps: Hybrid ideographic and geographic sign systems. In: Baumgärtner, Ingrid; Stercken, Martina (eds.), Herrschaft verorten: Politische Kartographie des Mittelalters und der Frühen Neuzeit. Zürich: Chronos, 335-353.

- 2012c. Signs from the life of organisms, species, languages, and the media. In: Maran, Timo; Lindström, Kati; Magnus, Riin; Tønnessen, Morten (eds.), Semiotics in the Wild: Essays in Honour of Kalevi Kull on the Occasion of His 60th Birthday. Tartu: University of Tartu Press, 123-130.

- 2014a. The life of symbols and other legisigns: More than a mere metaphor? In: Romanini, Vinicius; Eliseo, Fernandez (eds.), Peirce and Biosemiotics: A Guess at the Riddle of Life. Heidelberg: Springer, 171-182.

- 2014b. Three paradigms of iconicity research in language and literature. In: Shinohara, Kazuko; Akita, Kimi; Hiraga, Masako (eds.), East Meets West: Iconicity in Language and Literature. Amsterdam: Benjamins.

- 2014c. The semiotics of learning new words. Journal of the Philosophy of Education 48(3): 446-65.

- 2014d. Signs as educators: Peircean insights. In: Semetsky, Inna; Stables, Andrew (eds.), Pedagogy and Edusemiotics. Rotterdam: Sense, 446-65.

Nöth, Winfried; Santaella, Lucia 2011. Meanings and the vagueness of their embodiments. In: Thellefsen, Torkild; Sørensen, Bent; Cobley, Paul (eds.), From First to Third via Cybersemiotics - A Festschrift Honoring Professor Søren Brier on the Occasion of his 60th Birthday. Copenhagen: SL forlagene, 247-282.

Papineau, David 1987. Reality and Representation. Oxford: Blackwell.

Peirce, Charles S., see CP, EP, MS, SS, W.

Ransdell, Joseph. 1992. Teleology and the autonomy of the semiosis process. In: Balat, Michel; Deledalle-Rhodes, Janice; Deledalle, Gerard (eds.). Signs of Humanity - L'homme et ses signes. Vol. 1. Berlin: Mouton de Gruyter, 43-48.

Robin, Richard S. 1967. Annotated Catalogue of the Papers of Charles S. Peirce. Amherst: University of Massachusetts Press.

Santaella, Lucia 1999. A new causality for the understanding of the living. Semiotica 127: 497-519.

Short, Thomas L. 1983. Teleology in nature. American Philosophical Quarterly 20: 311-320.

- 1988. The growth of symbols. Cruzeiro semiótico (Porto) 8: 81-87.

SS $=$ Peirce, Charles S. 1977. Semiotics and Significs: The Correspondence between Charles

S. Peirce and Victoria Lady Welby. [Hardwick, Charles S., ed.] Bloomington: Indiana University Press.

Turley, Peter T. 1977. Peirce's Cosmology. New York: Philosophical Library.

$\mathrm{W}=$ Peirce, Charles S. 1982-. The Writings of Charles S. Peirce. A Chronological Edition. [Fisch, Max H. et al., eds.] Bloomington: Indiana University Press. [In-text references are to W, followed by volume number.] 


\section{Рост знаков}

В статье рассматривается теория семиозиса в контексте пирсовской философии эволюции. Исходя из тезиса, что символы растут путем инкорпорирования индексов и икон, автор предлагает ответы на следующие вопросы: Что имеет в виду Пирс, говоря о «саморазвитии знаков» в природе и культуре, считая при этом символы живыми? Как знаки растут? Растут ли все знаки или только символы? Предполагает ли рост знаков семиотическую агентность, и если так, то кто является действующим лицом в семиозисе при росте знаков и знаковых систем? В статье рассматриваются доводы культурологов и историков языка в противовес предположению, что знаки могут еще расти и растут в комплексных культурах; сравнивается пирсовская теория семиотического роста с меметическими и телеосемиотическими теориями.

\section{Märkide kasvamine}

Käesolevas artiklis vaadeldakse semioositeooriat Peirce'i evolutsioonifilosoofia kontekstis. Keskendudes teesile, et sümbolid kasvavad indekseid ja ikoone inkorporeerides, pakutakse vastuseid järgmistele küsimustele: Mida mõtleb Peirce "märkide isearengu" all looduses ja kultuuris ning sümbolite kui elusolendite all? Kuidas märgid kasvavad? Kas kasvavad kõik märgid või ainult sümbolid? Kas märkide kasvamine eeldab semiootilist agentsust ja kui see on nii, siis kes on semioosis toimijad, kui märgid ja märgisüsteemid kasvavad? Artiklis käsitletakse kultuuriuurijate ja keeleajaloolaste vastuväiteid oletusele, et märgid võivad ikka veel kasvada ning kasvavad komplekssetes kultuurides, tõmmatakse paralleele Peirce'i semiootilise kasvu teooria ning memeetika ja teleosemiootika teooriate vahel ning osutatakse nende erinevustele. 